\title{
Marbled Murrelets Select Distinctive Nest Trees within Old-Growth Forest Patches
}

\section{Sélection d'arbres de nidification distinctifs dans les îlots de vieilles forêts par le Guillemot marbré}

\author{
$\underline{\text { Michael P. Silvergieter }}^{1}$ and $\underline{\text { David B. Lank }}^{1}$
}

\begin{abstract}
The coastal old-growth forests of North America's Pacific Coast are renowned both for their commercial and ecological value. This study adds to growing evidence that selective harvesting of the largest trees may have a disproportionate ecological impact. Marbled Murrelets (Brachyramphus marmoratus), a threatened species, nest almost exclusively in these old-growth forests. Detailed knowledge of nesting habitat selection provides guidance for habitat management and conservation. Habitat selection for this species has been studied at a variety of scales using ground and remote methods. However, because Marbled Murrelet nesting activity is limited to a single mossy platform on a single tree, we investigated nest tree selection within old-growth forest patches, using a set of 59 forest patches containing active nests. Nest trees were usually distinctive compared with neighboring trees in the surrounding $25 \mathrm{~m}$ radius patch. They averaged 15 to $20 \%$ taller than neighboring trees depending on region, had significantly larger stem diameters, more potential nesting platforms, and more moss. They had the most extreme values of height and width about three times as often as expected by chance. An analysis of moss platform use as a function of number of platforms per platform tree suggests that murrelets select individual platforms, rather than platform trees per se. Nonetheless, highly selective logging practices that remove high-value trees from stands may also remove trees most likely to be selected by nesting murrelets.
\end{abstract}

RÉSUMÉ. Les vieilles forêts de la côte nord-américaine du Pacifique sont renommées à la fois pour leur valeur commerciale et leur valeur écologique. Les résultats de nos travaux corroborent les observations sans cesse grandissantes voulant que la coupe sélective des arbres les plus gros puisse avoir un effet écologique disproportionné. Or, le Guillemot marbré (Brachyramphus marmoratus), espèce menacée, niche presque exclusivement dans ces vieilles forêts. La connaissance détaillée du processus de sélection des habitats de nidification est donc importante pour l'aménagement et la conservation d'habitats. C'est la raison pour laquelle la sélection de l'habitat par cette espèce a été étudiée à diverses échelles au moyen de méthodes sur le terrain et à distance. Toutefois, parce que l'activité des guillemots au moment de la nidification se limite à une unique plateforme de mousses dans un seul arbre, nous avons examiné la sélection des arbres de nidification dans les îlots de vieilles forêts à partir d'un échantillonnage de 59 îlots forestiers contenant des nids actifs. Les arbres sélectionnés présentaient habituellement des caractéristiques distinctives comparativement aux arbres avoisinants dans un rayon de $25 \mathrm{~m}$. Ainsi, ils étaient de 15 à $20 \%$ plus grands en moyenne que les arbres avoisinants selon la région, avaient un diamètre plus grand, et contenaient davantage de plateformes potentielles et de mousses. De plus, ces arbres se sont avérés être les plus grands et les plus gros des îlots, soit trois fois plus souvent environ qu'attendu du hasard. Par ailleurs, l'analyse de l'utilisation des plateformes de mousses, selon le nombre de plateformes par arbre potentiel, indique que les guillemots sélectionnent les plateformes plutôt que les arbres. Néanmoins, les

${ }^{1}$ Simon Fraser University

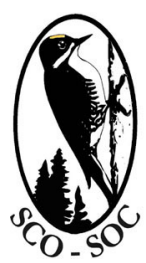

Sponsored by the Society of Canadian Ornithologists and Bird Studies Canada

Parrainée par la Société des ornithologistes du Canada et Études d'oiseaux Canada

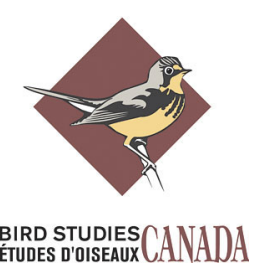


pratiques très sélectives d'exploitation forestière, qui favorisent la récolte des arbres de grande valeur dans les peuplements, pourraient également mener à la récolte d'arbres ayant une forte probabilité de sélection par les guillemots au moment de la nidification.

Key Words: Brachyramphus marmoratus; British Columbia; habitat selection; Marbled Murrelet; nest tree

\section{INTRODUCTION}

Nest site selection by birds results from a series of behavioral choices. Habitat characteristics of the nest site itself, and at various scales surrounding the nest site, entail variation in predation danger, resources, and environmental conditions, which affect individual nest success and ultimately population persistence (Johnson 2007). Understanding nest site selection therefore leads to better definitions and measures of habitat quality, defined by Hall et al. (1997) as the ability of a given habitat to support individuals or populations and allow them to persist through time. Measures of habitat quality are used by managers to rank and prioritize habitats for conservation.

Loss of old-growth nesting habitat for Marbled Murrelets (Brachyramphus marmoratus) has been identified as the major factor responsible for population declines and local extirpation, and management of nesting habitat is a key part of the recovery strategy for this threatened species in Canada (Canadian Marbled Murrelet Recovery Team 2003) and the United States (U.S. Fish and Wildlife Service 1997). Marbled Murrelet nests are usually located on large limbs that offer a soft substrate of epiphytes (moss) or accumulated lichen and duff into which a depression is formed to hold a single egg (Nelson 1997). Limbs of sufficient size to contain nests are referred to as platforms; these limbs are typically at least $15 \mathrm{~m}$ above the ground and at least $15 \mathrm{~cm}$ in diameter (Resource Inventory Committee 2001). These platforms occur almost exclusively in old-growth coniferous trees at least 140 years old (Burger 2002). For the purposes of this study, the term "platform trees" refers to canopy trees that contain at least one platform, as determined by observers from the ground.

Nest site selection for Marbled Murrelets and other species occurs at various scales, and can be viewed as a hierarchical process whereby decisions made at one scale constrain the available habitat from which subsequent choices are made at finer scales.
Studies of habitat selection must carefully define "available" habitat (Jones 2001), and Johnson (1980) provides us the tools to do so in the form of selection orders. For Marbled Murrelets, nesting habitat selection at the landscape scale (third order a, in Meyer 2007) is positively influenced by availability of old-growth forest (Burger 2002, Raphael et al. 2002), increased topographic complexity (Waterhouse et al. 2009), elevation, i.e., positive or negative influence (Burger 2002), and moister climate zones, i.e., fog-influenced zones in California and Oregon, based on behavioral indicators of nesting (Meyer et al. 2004), and north and west slope aspects in B.C. (Silvergieter 2009). Selection for nest patches within the landscape (third order b, in Meyer 2007) is based on larger mean tree size, i.e., stem diameter as well as canopy height, canopy structure and complexity, and greater densities of potential platforms and platform trees (Burger 2002 for summary). These habitat variables discriminate nest patches from available habitat (Hamer et al. 2008, Waterhouse et al. 2008, 2009, Silvergieter 2009) using either ground or remote, i.e., air photo interpretation or low-level aerial surveys, methods of habitat assessment. The integration of ground and remote methods has not been well-studied, with Silvergieter (2009) offering results of one such comparison.

Understanding selection at fine scales provides a biological perspective for explaining patterns found at larger scales (Johnson 2007). Selection for the nest tree within the patch, referred to as elementlevel selection (Manley 1999), or fourth order habitat selection (Meyer 2007), is not well studied for Marbled Murrelets because few nests have actually been found. Manley (1999) showed that nest trees, as a population, were taller and had more platforms than samples of other trees in the forest patches surrounding the nest trees. At Clayoquot Sound, British Columbia, Conroy et al. (2002) found that five nest trees had a larger stem diameter at breast height (DBH) and more platforms than other trees in the valley. 
Between 1998 and 2002, researchers used radio telemetry in southern British Columbia to locate the largest set of Marbled Murrelet nests yet found (Bradley et al. 2004, Piatt et al. 2007). Photographs of these nests, nest trees, and sites in their landscape setting are available at http://www.sfu.ca/biology/w ildberg/mamuweb/welcome.htm. This set of nests has been used for habitat selection studies of landscape features (Zharikov et al. 2006, 2007) and nest patches using air photo interpretation (Waterhouse et al. 2004, 2008), low-level aerial surveys (Waterhouse et al. 2009), and ground-based surveys (Silvergieter 2009). Although descriptions of habitat selection at larger scales are directly applicable to management questions and apply over large areas, murrelet activity is limited to a single platform in a single tree. Some of the nests located by radio telemetry were in large veteran trees within a matrix of otherwise unsuitable habitat (Zharikov et al. 2006), suggesting that in some cases, characteristics of the single nest tree may be more important for selection than those of the surrounding patch.

The available habitat in this study is defined as the patch surrounding the nest tree; it seems safe to assume that these nearby trees were equally available to the prospecting murrelet. We thus compared nest trees to all other canopy trees within $25 \mathrm{~m}$ and to the subset of those trees containing platforms, i.e., platform trees, hypothesizing that nest trees are distinguishable from those in the surrounding patch. We estimate the chances of the nest tree having extreme values for a variety of measures, given the number and attributes of other trees in the patch. We call nest trees distinctive if they are statistically significantly larger, taller, or have more moss or platforms; however, these trees are not necessarily the superlative tree in any particular dimension. Our null hypothesis is that each nest tree has a $1 / \mathrm{n}$ chance of being distinctive, where $n$ is the number of canopy or platform trees within each plot. We present a cumulative likelihood of being distinctive based on the weighted Z-method (Whitlock 2005), and summarize the number of plots containing distinctive nest trees.

Several studies report that murrelets select trees with more platforms (Manley 1999, Conroy et al. 2002). However, no previous study has tested whether this pattern results from selection favoring the use of trees with more platforms, or simply matches the distribution expected from variation in the number of platforms available in each tree. We examine patterns of usage versus availability of platforms among platform trees to look for evidence of selection occurring for trees with more platforms.

If nest trees are distinct from neighboring trees in the patch, the presence of such distinctive trees would be an important characteristic of nest patches. Focusing on actual nest site selection at the element scale should help explain the functional significance of patterns of patch-level habitat selection and thereby habitat quality from a management perspective. Both nest searches and management decisions may be improved given knowledge of nest site selection at this scale. Selective logging practices in particular, whereby the largest trees are removed from a stand, may have a larger than expected impact on existing and potential murrelet nest densities.

\section{METHODS}

\section{Study area}

The study took place at Clayoquot Sound (CS; $49^{\circ}$ $12^{\prime}$ N, $126^{\circ} 06^{\prime} \mathrm{W}$ ) and Desolation Sound (DS; $50^{\circ}$ $05^{\prime} \mathrm{N}, 124^{\circ} 40^{\prime} \mathrm{W}$ ) on the southern coast of British Columbia, two regions with relatively large populations of nesting murrelets. Birds were captured at sea and outfitted with radio tags during the breeding season. Nest sites were located by radio telemetry at CS (2000-2002) and DS (1999-2001) and monitored by helicopter for presence-absence patterns indicative of incubation (see Bradley et al. 2004, Zharikov et al. 2006).

Although 157 nests were located, many were inaccessible to ground crews $(n=87)$, especially at DS, and are therefore not included in this study, which requires ground-based sampling. One nest in lower portions of a deciduous tree (red alder, Alnus rubra; Bradley and Cooke 2001) was also omitted, because it is the only deciduous nest known for this species, and we consider it an outlier with respect to nesting habitat in this region. We also excluded 10 sites where either habitat plot data were not available or the nest tree was not confirmed within the plot. In another study using this dataset, Silvergieter (2009) found that plots with fewer than five canopy trees measured were not representative of the area. Seventeen sites containing five or fewer canopy trees were eliminated for this reason. The study is thus based on 59 sites, some of which were 
missing epiphyte data; sample sizes are therefore reported individually for epiphyte variables. Limited accessibility could introduce some bias relative to patterns over all sites, but any such bias may be of less concern for this study, which focuses within patches, than it would be for studies comparing choices among patches at the landscape scale. Finally, the accessible habitat to which these models apply is most representative of that used by current commercial logging, and therefore of highest immediate conservation value.

\section{Field techniques}

Ground vegetation surveys were carried out according to established "RIC" protocols for Marbled Murrelet nesting habitat (Resource Inventory Committee 2001), whereby all trees (> $10 \mathrm{~cm} \mathrm{DBH}$ ) are measured in a $25 \mathrm{~m}$ radius plot centered on the nest tree. The variables investigated in this study include: the DBH $(\mathrm{cm})$, tree height $(\mathrm{m})$, number of potential nesting platforms, estimated mean epiphyte cover on limbs $(0=$ none; $1=$ trace; $2=1-33 \%$ cover; $3=34-66 \%$ cover; $4=67-100 \%$ ), and epiphyte thickness ( $1=$ sparse; $2=$ intermediate; $3=$ thick mats). Canopy height was measured using a clinometer for nest trees and certain other trees in the patch, as a reference by which other tree heights were estimated. Heights of nest trees were more accurately estimated by climbers with measured ropes. Canopy trees were determined by ground observers, defined as trees that reach the uppermost continuous layer of tree crowns or higher.

For nest trees, both ground-based and climber counts were available for the number of potential platforms, and these were often different, with climber counts generally greater than ground estimates. This is consistent with Rodway and Regehr (1999), who found that ground observers tended to underestimate actual platform abundance, except for trees with few actual platforms, when ground observers tended to overestimate. In this study ground-based counts were used in all cases to allow comparison to other trees, therefore the data we use likely underestimate actual platform abundance. It should be noted that in this study the term "non-nest tree" refers to trees other than confirmed nest trees, though the absence of nests in these trees was not confirmed. Active nests are very unlikely in non-nest trees because of low nest densities (Conroy et al. 2002), but they may have contained nests from previous years.

\section{Statistical analysis}

Variables at many sites were not normally distributed and often had small sample sizes, therefore nonparametric Sign tests were used to determine, for each variable, whether nest trees were significantly different $(\mathrm{P}<0.05)$ from other trees in the plot. Nest trees were compared to each of the neighboring trees in the plot. We used the weighted Z-method (Whitlock 2005) to obtain a measure of combined significance for each variable, with weight equivalent to the sample size of neighboring trees in each plot. We considered a nest tree to be distinctive if it was significantly larger, or had significantly more platforms, moss, etc. than other trees in the plot. For comparisons involving only platform trees, we omitted any sites with fewer than six other platform trees, resulting in a smaller sample size of 40 for these analyses. All means are presented \pm one standard error. Spearman rank correlations were used to investigate whether nest trees that were significantly different in one variable were also likely to differ in other respects.

We investigated selectivity for platform tree species within a site under the null hypothesis that each platform tree had an equal probability of being chosen. We calculated selectivity score $(S)$ for each tree species represented in each plot, as the difference between observed probability of usage, i.e., one for the species in that plot, zero for nonnest species, and the expected probability of usage, i.e., the proportion of platform trees of that species in the plot. Therefore, the scores for nest tree species ranged from 0 to 1 for each plot; nest tree species that were rare among platform trees in the plot would have higher scores. Conversely, non-nest tree species scores ranged from $>-1$ to 0 , with common species in the plot having higher scores. We used ANOVA to test for variation among the mean scores of tree species across all plots.

Our data also allow us to assess whether murrelets choose trees with more platforms to use as nest trees, or whether they choose individual platforms with no contribution from the number of platforms per tree. Among trees with one or more platforms, we investigated whether trees were used proportionately more or less than expected if platforms were used at random with respect to the number per tree. The null hypothesis is that a platform has an equal chance of being used or not independently of the number of platforms per tree. We tested this with a Kolmogorov-Smirnov 2-Sample test, which 
Table 1. Nest tree characteristics by dimension and tree species. Nests were found in a variety of tree species, with most in western hemlock and douglas-fir. Nest trees had, on average, eight potential nesting platforms, and were shorter at Clayoquot Sound (CS) compared with Desolation Sound (DS).

\begin{tabular}{|c|c|c|c|c|c|c|c|c|c|}
\hline \multirow[b]{2}{*}{ Species } & \multirow{2}{*}{$\frac{\text { Total }}{n}$} & \multirow{2}{*}{$\frac{\mathrm{CS}}{n}$} & \multirow{2}{*}{$\frac{\mathrm{DS}}{n}$} & \multicolumn{2}{|c|}{ DBH $(\mathrm{cm})$} & \multicolumn{2}{|c|}{ Height (m) } & \multicolumn{2}{|c|}{ Platforms } \\
\hline & & & & Mean & $\pm \mathrm{SE}$ & Mean & $\pm \mathrm{SE}$ & Mean & $\pm \mathrm{SE}$ \\
\hline $\begin{array}{l}\text { Western Hemlock } \\
\text { (Tsuga heterophylla) }\end{array}$ & 20 & 12 & 8 & 94.0 & \pm 6.2 & 37 & \pm 2 & 8 & \pm 0 \\
\hline $\begin{array}{l}\text { Mountain Hemlock } \\
\text { (Tsuga mertensiana) }\end{array}$ & 1 & 1 & 0 & 162.2 & & 42 & & 20 & \\
\hline $\begin{array}{l}\text { Douglas Fir } \\
\text { (Pseudotsuga menziesii) }\end{array}$ & 16 & 5 & 11 & 137.9 & \pm 7.2 & 48 & \pm 2 & 8 & \pm 1 \\
\hline $\begin{array}{l}\text { Western Red Cedar } \\
\text { (Thuja plicata) }\end{array}$ & 11 & 3 & 8 & 154.9 & \pm 16.7 & 45 & \pm 2 & 7 & \pm 1 \\
\hline $\begin{array}{l}\text { Yellow Cedar } \\
\text { (Callitropsis } \\
\text { nootkatensis) }\end{array}$ & 6 & 5 & 1 & 89.8 & \pm 10.8 & 32 & \pm 2 & 8 & \pm 2 \\
\hline $\begin{array}{l}\text { Amabilis Fir } \\
\text { (Abies amabilis) }\end{array}$ & 5 & 1 & 4 & 107.9 & \pm 10.8 & 57 & \pm 5 & 10 & \pm 2 \\
\hline CS & & 27 & - & 107.3 & \pm 7.9 & 38 & \pm 2 & 8 & \pm 1 \\
\hline DS & & - & 32 & 121.8 & \pm 8.2 & 48 & \pm 2 & 8 & \pm 1 \\
\hline All & 59 & & & 119.2 & \pm 5.4 & 43 & \pm 1.4 & 8 & \pm 0.5 \\
\hline
\end{tabular}

compares the cumulative distribution of all non-nest tree platforms with respect to the number of platforms in each non-nest tree, versus the cumulative distribution of all nest tree platforms with respect to the number of platforms in each nest tree. A difference between these distributions would suggest preferences for the usage of, or against, trees with particular numbers of platforms.

\section{RESULTS}

Fifty-nine nest trees and 1240 non-nest trees were measured in the study, with $21.0 \pm 0.2$ (mean $\pm \mathrm{SE}$ ) trees in $25 \mathrm{~m}$ plots (range $5-50 ; n=59$ ), and 10.7 \pm 0.2 platform trees (range $5-25$ ). Although taken as a whole there may be selection for certain species, comparisons within sites show no species preference. The nest tree species was the most common species of platform tree in the surrounding plot at $81 \%$ of sites at CS and $72 \%$ of sites at DS.
Cumulatively, there appears to be selection for douglas-fir (Pseudotsuga menziesii) at both CS (comprising $35 \%$ of nests compared to $11 \%$ of all platform trees) and DS (19\% of nests, $8 \%$ overall).

Among nest trees, western hemlock (Tsuga heterophylla) and yellow cedar (Callitropsis nootkatensis) were notably smaller in terms of DBH and height than other species (Table 1). Among the 59 nest sites, nest trees had a DBH of $119.2 \pm 5.4$ $\mathrm{cm}$, were $43 \pm 1 \mathrm{~m}$ tall and contained $8 \pm 1$ platforms. Nest trees at CS $(n=28)$ were significantly shorter than those at DS $(n=31$; Table 1; two-sample t-test, $\left.\mathrm{t}_{(57)}=-3.32, \mathrm{P}<0.01\right)$, but were similar in other respects.

Nest tree diameters averaged $43.7 \mathrm{~cm}$ greater than other canopy trees in their plot. Nest trees had significantly greater diameters than other canopy trees at $64 \%$ of sites (Table 2; Weighted Z-method for combined probabilities: $Z_{w}=-31.20, P<0.01$ ), 
Table 2. Comparison of nest trees to all other canopy trees and to trees containing platforms within $25 \mathrm{~m}$ with respect to diameter at breast height $(\mathrm{DBH})$, height, platforms, and epiphyte growth. $\mathrm{CS}=\mathrm{Clayoquot}$ Sound, DS = Desolation Sound.

\begin{tabular}{|c|c|c|c|c|c|c|c|c|c|}
\hline \multirow[b]{2}{*}{ Variable } & \multirow[b]{2}{*}{ Region } & \multicolumn{4}{|c|}{ All canopy trees } & \multicolumn{4}{|c|}{ Platform trees only } \\
\hline & & $n$ & $\begin{array}{c}\text { Mean } \\
\text { difference } \\
\text { from nest tree }\end{array}$ & $\begin{array}{l}\% \text { Nest trees } \\
\text { sig. different }{ }^{\dagger}\end{array}$ & $\begin{array}{l}\% \text { Nest } \\
\text { trees } \\
\text { highest } \\
\text { ranked }\end{array}$ & $n$ & $\begin{array}{l}\text { Mean difference } \\
\text { from nest tree }\end{array}$ & $\begin{array}{l}\% \text { Nest trees } \\
\text { sig. different }{ }^{\dagger}\end{array}$ & $\begin{array}{l}\% \text { Nest trees } \\
\text { highest ranked }\end{array}$ \\
\hline \multirow[t]{3}{*}{$\mathrm{DBH}(\mathrm{cm})$} & $\mathrm{CS}$ & 27 & $33.7 \pm 6.2$ & $67^{\ddagger}$ & 26 & 22 & $23.8 \pm 6.8$ & $41^{\ddagger}$ & 27 \\
\hline & DS & 32 & $52.2 \pm 8.3$ & $63^{\ddagger}$ & 34 & 18 & $19.0 \pm 11.0$ & $28^{\ddagger}$ & 22 \\
\hline & Both & 59 & $43.7 \pm 5.4$ & $64^{\ddagger}$ & 31 & 40 & $21.6 \pm 6.1$ & 35 & 25 \\
\hline \multirow[t]{3}{*}{ Height (m) } & $\mathrm{CS}$ & 27 & $5.0 \pm 1.3$ & $63^{\ddagger}$ & 30 & 22 & $2.8 \pm 1.3$ & $41^{\ddagger}$ & 32 \\
\hline & DS & 32 & $11.2 \pm 1.7$ & $72^{\ddagger}$ & 41 & 18 & $6.3 \pm 2.1$ & $33^{\ddagger}$ & 33 \\
\hline & Both & 59 & $8.4 \pm 1.1$ & $68^{\ddagger}$ & 36 & 40 & $4.4 \pm 1.2$ & 38 & 33 \\
\hline \multirow[t]{3}{*}{ Platforms } & $\mathrm{CS}$ & 27 & $7 \pm 1$ & $96^{\ddagger}$ & 44 & 22 & $5 \pm 1$ & $73^{\ddagger}$ & 36 \\
\hline & DS & 32 & $6 \pm 1$ & $88^{\ddagger}$ & 53 & 18 & $5 \pm 1$ & $61^{*}$ & 44 \\
\hline & Both & 59 & $6 \pm 1$ & $92^{\ddagger}$ & 49 & 40 & $5 \pm 1$ & 68 & 40 \\
\hline \multirow{3}{*}{$\begin{array}{l}\text { Epiphyte } \\
\text { Cover }^{8}\end{array}$} & $\mathrm{CS}$ & 27 & $0.4 \pm 0.1$ & $41^{\ddagger}$ & 0 & 22 & $0.1 \pm 0.1$ & 14 & 0 \\
\hline & DS & 30 & $0.4 \pm 0.1$ & $40^{\ddagger}$ & 0 & 14 & $0.0 \pm 0.2$ & 21 & 0 \\
\hline & Both & 57 & $0.4 \pm 0.1$ & $40^{\ddagger}$ & 0 & 36 & $0.0 \pm 0.1$ & 17 & 0 \\
\hline \multirow{3}{*}{$\begin{array}{l}\text { Epiphyte } \\
\text { Thickness }\end{array}$} & $\mathrm{CS}$ & 27 & $0.6 \pm 0.1$ & $74^{\ddagger}$ & 0 & 21 & $0.3 \pm 0.1$ & $19^{\ddagger}$ & 0 \\
\hline & DS & 26 & $0.8 \pm 0.1$ & $58^{\ddagger}$ & 0 & 11 & $0.3 \pm 0.1$ & $9^{\ddagger}$ & 0 \\
\hline & Both & 53 & $0.7 \pm 0.1$ & $66^{\ddagger}$ & 0 & 32 & $0.2 \pm 0.1$ & 10 & 0 \\
\hline
\end{tabular}

Sign test $\mathrm{P}<0.05$.

Combined significance $\mathrm{P}<0.05$ (weighted Z-method; Whitlock 2005).

${ }^{\S}$ Categories; see Methods.

were the largest tree at $31 \%$ of sites, and were among the five largest trees at $69 \%$ of sites. Nest trees were significantly larger than other platform trees at $35 \%$ of sites $\left(Z_{w}=-8.06, P<0.01\right)$.

Nest trees were also taller, by $8.4 \mathrm{~m}$ on average, than neighboring canopy trees. Nest trees were significantly taller at $68 \%$ of sites (Table $2 ; \mathrm{Z}_{\mathrm{w}}$ $=-26.89, \mathrm{P}<0.01)$. They were the tallest tree within
$25 \mathrm{~m}$ at $36 \%$ sites, and were among the five tallest trees at $76 \%$ of sites. Nest trees were significantly taller than other platform trees at $38 \%$ of sites $\left(Z_{w}\right.$ $=-7.82, \mathrm{P}<0.01)$ with an average difference of 4.4 $\pm 1.2 \mathrm{~m}(n=59)$, and nest trees were significantly shorter than other trees at three sites.

Nests occurred in six species of trees. Western hemlock was the most common nest tree species at 
Fig. 1. Cumulative proportion of platforms in non-nest trees (solid line) and platforms in nest trees (dashed line) as a function of trees with a given number of platforms. Although the distributions are not significantly different (Kolmogorov-Smirnov 2-sample test: $\mathrm{KSa}=0.79, \mathrm{P}=0.33$ ), trees with fewer than three to four platforms appear to be underused. Platforms $n=2609$; platform trees $n=533$.

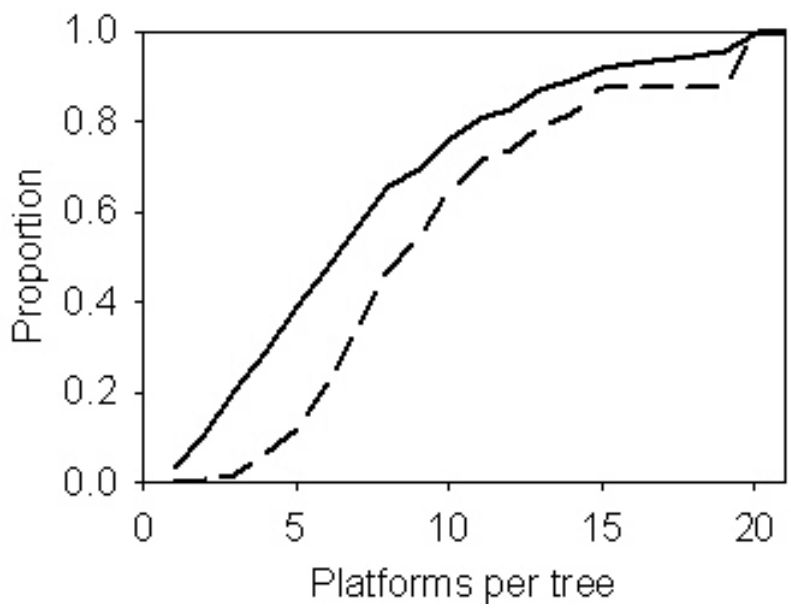

CS, and douglas-firs contained most of the nests at DS, with western red cedar (Thuja plicata) and western hemlock as the next most frequently used species (Table 1). All of the species that contained platforms were represented among nest trees except for sitka spruce (Picea sitchensis) and bigleaf maple (Acer macrophyllum), both of which were infrequent as available trees. Douglas-fir (present in 20 plots, $S=0.27 \pm 0.09)$ and yellow cedar $(n=$ $13 ; \mathrm{S}=0.08 \pm 0.13$ ) were the only species that may have been used on average more than expected, however there was no significant difference among the means (ANOVA F $=1.59, \mathrm{p}=0.14$, df $=7$; Levene's test showed acceptable homogeneity of variances $(F=1.50, p=0.18, d f=6)$.

We limit our analysis of number of platforms to trees containing at least one platform. In every plot, the nest tree contained more platforms than the average in nearby available trees. Nest trees had significantly more platforms at $68 \%$ of the sites (Table 2; $\mathrm{Z}_{\mathrm{w}}=-14.62, \mathrm{P}<0.01$ ), containing, on average, $5 \pm 1(n=59)$ more platforms than other platform trees.

Do murrelets choose platforms or platform trees? The probability that a tree was used as a nest tree with respect to the number of platforms per tree was not significantly different from what would be expected from the number of platforms available in non-nest trees with different numbers of platforms
(Fig. 1). Although it appears that murrelets avoided trees with fewer than three to four platforms, we have no overall statistical support for selection of trees with more platforms per se. Instead, in general, platforms were used as expected based on the proportion of platforms available in trees with different numbers of platforms.

Epiphyte thickness and cover were ranked on scales consisting of three and four categories, respectively. Differences are therefore more difficult to detect. Nonetheless, nest trees had significantly more overall epiphyte cover than other trees at $40 \%$ of sites (Table $2 ; Z_{\mathrm{w}}=-11.88, \mathrm{P}<0.01$ ), and $66 \%$ of nest trees $\left(Z_{w}=-25.94, P<0.01\right)$ had significantly thicker epiphyte cover. Compared with other platform trees, nest trees did not have more epiphyte cover $\left(Z_{w}=-0.99, P=0.16\right)$. Nest trees did have significantly thicker epiphytes than neighboring platform trees, with a combined significance of $\mathrm{P}<$ $0.01\left(Z_{w}=-3.40\right)$, though only $16 \%$ of nest trees were distinctive in this respect.

The differences between nest trees and neighboring canopy or platform trees were similar at CS and DS, except with regard to height. The average difference in height between nest trees and neighboring trees was significantly larger at DS than at CS (MannWhitney U-test: $5.0 \pm 1.3, n=28$ at CS, $11.2 \pm 1.7$, $n=31$ at DS; $\mathrm{U}=1001.0, \mathrm{P}<0.01$; Table 2). 
Table 3. Spearman rank correlations show that nest trees that were distinct when compared with neighboring canopy trees (above diagonal; $n=59$, except $n=57$ for epiphyte cover, and $n=53$ for epiphyte thickness) and neighboring platform trees (below diagonal; $n=40$, except $n=36$ for epiphyte cover, and $n=32$ for epiphyte thickness) are often distinct in other dimensions as well. $\mathrm{DBH}=$ diameter at breast height.

\begin{tabular}{lccccc}
\hline \hline & DBH & Height & Platforms & Epiphyte Cover & Epiphyte Thickness \\
\hline DBH & - & $0.67^{\dagger}$ & $0.40^{\dagger}$ & 0.11 & $0.27^{\dagger}$ \\
Height & $0.52^{\dagger}$ & - & 0.18 & 0.04 & 0.09 \\
Platforms & $0.38^{\dagger}$ & 0.03 & - & 0.12 & 0.23 \\
Epiphyte Cover & 0.24 & 0.26 & 0.30 & - & $0.33^{\dagger}$ \\
Epiphyte Thickness & $0.29^{\dagger}$ & -0.07 & $0.43^{\dagger}$ & 0.23 & - \\
\hline
\end{tabular}

${ }^{\dagger}$ Spearman rank correlation $\mathrm{P}<0.05$.

Nest trees were often distinguishable from other neighboring trees with respect to more than one variable. Nest trees with a significantly larger DBH also tended to be significantly taller than other trees and have more platforms and thicker epiphytes (Table 3). Trees with more epiphyte cover also had thicker epiphytes, and the correlation between trees with more platforms and epiphyte thickness was marginally significant $(\mathrm{P}=0.07)$. Though statistically significant, correlations show considerable noise in the data. Similar results were seen when comparing only among trees with platforms (Table 3).

\section{DISCUSSION}

\section{Nest trees are distinctive}

Trees chosen by Marbled Murrelets for nesting can often be distinguished from other trees in the immediate vicinity in terms of their size, number of platforms, and, to a lesser extent, a general ranking of epiphyte cover and thickness. Using a cumulative measure of significance weighted by the sample size of individual plots, nest trees were usually significantly different from neighboring trees in one or more dimensions. Though not always the superlative tree among its neighbors, this study shows that murrelets do tend to select distinctive trees, based on size and platform number, from among the canopy and platform-containing trees in the immediate vicinity. In contrast to these characteristics, and as found in previous studies (Burger 2002), there does not appear to be strong selection with respect to tree species.

The traditional habitat selection study design whereby one compares used sites to unused or available sites using logistic regression, or some similar design, is complicated in studies of element scale, i.e., nest site within patch, selection for animals exhibiting low nest densities because a patch will contain just one used site. By comparing each nest tree to its immediate neighbors, and applying a measure of cumulative significance weighted by the sample size for each plot, we have shown that selection for nest trees is nonrandom at this scale.

In a similar study of primarily high elevation nests (range 688-1260 m; mean $=886 \mathrm{~m})$ at DS, Manley (1999) found evidence of selection for taller nest trees with greater DBH and more platforms. Manley compared a pooled sample of nest trees to all other trees measured, rather than the within-patch comparison made in our study. Conroy et al. (2002) also found that nest trees at CS had significantly larger DBH than other potential trees that were climbed, but nest trees did not differ in terms of height or number of platforms, particularly in better quality habitat. Conroy et al. (2002) used a sample of five nest trees, and also used pooled samples for comparisons. Three studies, including the present, 
using different methodologies, provide strong evidence that nest trees consistently have larger relative $\mathrm{DBH}$ than non-nest trees.

Selection has also been observed at the patch level for canopy height, $\mathrm{DBH}$, and density of platform trees (Silvergieter 2009), indicating that selection for these variables may occur at both scales. Nest success did not vary with respect to habitat variables at various scales (Silvergieter 2009). These results may be used to help direct tree-climbing nest searches, which can be very inefficient when searching every potential platform tree (Conroy et al. 2002). Trees that are taller have more platforms and more epiphytes than neighboring trees within the patch, are visually distinctive from the ground, and are the most likely to contain a nest in occupied patches.

One of the most striking results is the height of nest trees compared with neighboring trees. Nest trees were often much taller than other available trees, with an average difference amounting to $15 \%$ of the total height at CS and $30 \%$ at DS. Nest trees were also $8 \%$ (at CS) to $15 \%$ (at DS) taller than other platform trees. Nest trees are not always the tallest tree among their neighbors, but $\sim 36 \%$ were, and $76 \%$ were among the top five tallest trees in a patch; as a group they were significantly taller than the average canopy height in the vicinity. Such differences would be visually distinguishable in the aerial surveys and air photos that are currently used to rank nesting habitat quality in British Columbia. This information would significantly reduce the number of probable nest trees in a given patch. Nest trees that are significantly taller than surrounding trees likely offer murrelets easier access to the canopy, as does canopy complexity or height variability, known to be important factors in patchscale habitat selection (Bahn and Newsom 2002, Waterhouse et al. 2004, Hamer et al. 2008). Tall nest trees may also provide a distinct landmark to aid commuting adults in locating the nest. In this way, our understanding of selection at the patch scale can help understand patterns observed at the element scale.

Evidence of preference for epiphyte cover and epiphyte thickness in nest trees was weaker than for other variables, possibly because of the categorical nature of these variables. Because some degree of epiphyte development is usually necessary for platform development, one may expect that while the nest tree may have more epiphytes than other canopy trees, the difference may be much less when only platform trees are considered. Nonetheless, more than a quarter of the nest trees considered here had significantly more epiphyte development than other nearby platform trees. Variation in epiphyte cover within the patch is likely due to tree species, $\mathrm{DBH}$, and proximity to small watercourses where epiphytes often appear to be more abundant (M. P. Silvergieter, personal observation).

Since DBH is roughly correlated with age, it is not surprising that trees distinctive in terms of DBH also tended to be taller and have thicker epiphytes. Thicker epiphytes and platform abundance are expected to show a positive correlation because epiphytes are an important component of potential nesting platforms.

\section{Is there a preference for trees with more platforms?}

The difference in DBH between nest trees and available trees observed in this study may be a correlated function of platform availability in the nest tree. Many studies have found that trees with larger DBH have more platforms (Hamer 1995, Naslund et al. 1995, Manley 1999), likely because of tree age. In this study, nest trees that had significantly larger DBH also tended to have more platforms when compared with neighboring trees. Furthermore, many fewer nest trees showed a significant difference in DBH when compared only with neighboring trees containing platforms.

Although the nest tree is often considered a unit of habitat selection, murrelets use only one platform for nesting. Within the patch, murrelets may either select trees with preferred characteristics, select preferred nest platforms that happen to occur in certain trees, or some combination of the two. Previous studies (Manley 1999, Conroy et al. 2002) have concluded that there was strong selection for trees with more platforms over other available trees. However, no previous study has tested whether murrelets actually prefer trees because they have more platforms versus utilizing platforms without respect to the number per tree. We looked for evidence of disproportionate usage of platforms as a function of their number per tree; if murrelets prefer trees with more platforms, we should have found a difference in the cumulative usage in nest trees, versus availability of platforms in non-nest trees, with respect to the number per tree. Trees with 
fewer than, e.g., three or four platforms do appear to be disproportionately avoided as nest trees (Fig. 1). However, we found no overall statistical support for a preference for using trees with more platforms beyond that expected from the number of platforms per tree. The simplest interpretation of this result is that murrelets chose particular platforms without respect to the number per tree. It suggests, for example, that two trees with five platforms each would have the same combined probability of being used by nesting murrelets as a single tree with 10 platforms.

\section{CONCLUSIONS}

The contrast between nest and adjacent trees suggests that individual trees within patches of otherwise less suitable habitat may be of significant value to Marbled Murrelets. Murrelets usually choose a nest tree with exaggerated characteristics not well represented by the overall patch. Such considerations may be most important at the edges of the range of suitable habitat, such as high elevation habitats where suitably large trees occur at low densities.

Bahn (1998) noted that most nest trees known at that time had more than three platforms, and suggested that potential nest trees be limited to those with at least that many platforms. In agreement with this, Figure 1 also suggests that trees with three or fewer platforms may be underutilized. On the other hand, six nests $(10 \%)$ in this study did occur in trees with three or fewer platforms, and at least two of the 52 nest trees in Manley's (1999) study had three or fewer platforms. Strict adoption of Bahn's proposed criteria would exclude a non-negligible portion of nest trees.

In British Columbia, techniques such as helilogging involve selective removal of larger veteran trees from old-growth patches that are less amenable to normal clear-cut forestry operations. Such distinctive trees may be of substantial value to nesting Marbled Murrelets, and their removal may have a disproportionate effect on the probability of patch usage. The response to nest tree removal in future years is unknown, and it is possible that murrelets would simply choose among the next largest trees. Burger et al. (2009) found that reuse of the same nest tree was relatively common, particularly at DS where habitat reduction is more significant. Whether reuse was by the same pair or different individuals was not known. Based on our results we infer that trees chosen by selective logging are also more likely than other trees to contain nests; therefore the impact of selective logging is higher than would be expected if murrelets chose nest trees at random with respect to size. The magnitude of that impact is at present not well understood.

Current management of Marbled Murrelet nesting does not identify potential individual nest trees, focusing rather on identifying areas of suitable habitat and maintaining patches of it within landscapes. This study shows that nests are likely in distinctive trees, often among the very largest, within forest patches and thus the importance of such trees should be emphasized within the criteria for determining habitat quality. Distinctive trees may or may not be sufficient on their own to provide high quality habitat, but where present are perhaps more likely to be selected for nesting than other available trees. Preference for heterogeneous forest patches with increased vertical canopy complexity has been well established by other studies, and is recognized in models for ranking habitat quality. We now know that selection for larger nest trees at the element scale likely contributes to this observed preference at the patch scale.

Responses to this article can be read online at: http://www.ace-eco.org/vol6/iss2/art3/responses/

\section{Acknowledgments:}

Thanks to R. Ydenberg, A. Burger, A. Salomon, L. Waterhouse, and an anonymous referee for valuable comments on previous drafts. Carl Schwarz provided statistical advice. Thanks to Fred Cooke, who initiated the nest study, and to various field assistants involved over the years. M. Silvergieter was supported by the Centre for Wildlife Ecology, a Simon Fraser University Graduate Fellowship, and an NSERC-CRD grant was awarded to D. Lank. Research was funded by the British Columbia Forest Science Program, Forest Investment Account, BC Timber Sales, and an NSERC-CRD grant which included Weyerhaeuser Canada Ltd., Cascadia Forest Products Ltd., Western Forest Products Inc., Terminal Forest Products Ltd., CANFOR Corp., and Island Timberlands LP as contributing industrial partners. 


\section{LITERATURE CITED}

Bahn, V. 1998. Habitat requirements and habitat suitability index for the Marbled Murrelet (Brachyramphus marmoratus) as a management target species in the Ursus Valley, British Columbia. Dissertation, Phillips-Universitat, Marburg, Germany.

Bahn, V., and D. Newsom. 2002. Habitat suitability mapping for Marbled Murrelets in Clayoquot Sound. Pages 101-119. in A. E. Burger and T. A. Chatwin, editors. Multi-scale studies of populations, distribution and habitat associations of Marbled Murrelets in Clayoquot Sound, British Columbia. Ministry of Water, Land and Air Protection, Victoria, British Columbia, Canada. [online] URL: http://www.env.gov.bc.ca/wld/documents/techpub/ mamuwebs.pdf

Bradley, R. W., and F. Cooke. 2001. Cliff and deciduous tree nests of Marbled Murrelets in southwestern British Columbia. Northwestern Naturalist 82:52-57. http://dx.doi.org/10.2307/3536786

Bradley, R. W., F. Cooke, L. W. Lougheed, and W. S. Boyd. 2004. Inferring breeding success through radiotelemetry in the Marbled Murrelet. Journal of Wildlife Management 68:318-331. http://dx.doi.org /10.2193/0022-541X(2004)068[0318:IBSTRI]2.0.CO;2

Burger, A. E. 2002. Conservation assessment of Marbled Murrelets in British Columbia: a review of the biology, populations, habitat associations and conservation. Technical Report Series 387, Pacific and Yukon Region, Canadian Wildlife Service, Environmental Conservation Branch, Delta, British Columbia, Canada. [online] URL: http://www.sfu.ca/ biology/wildberg/bertram/mamurt/PartA.pdf

Burger, A. E., I. A. Manley, M. P. Silvergieter, D. B. Lank, K. M. Jordan, T. D. Bloxton, and M. G. Raphael. 2009. Re-use of nest sites by Marbled Murrelets (Brachyramphus marmoratus) in British Columbia. Northwestern Naturalist 90:217-226. http://dx.doi.org/10.1898/NWN08-50.1

Canadian Marbled Murrelet Recovery Team. 2003. Marbled Murrelet conservation assessment 2003, Part B: Marbled Murrelet recovery team advisory document on conservation and management. Canadian Wildlife Service, Delta, British Columbia, Canada. [online] URL: http://www.sfu.ca/ biology/wildberg/bertram/mamurt/PartB.pdf

Conroy, C. J., V. Bahn, M. S. Rodway, L. Ainsworth, and D. Newsom. 2002. Estimating nest densities for Marbled Murrelets in three habitat suitability categories in the Ursus Valley, Clayoquot Sound. Pages 121-137 in A. E. Burger and T. A. Chatwin, editors. Multi-scale studies of populations, distribution and habitat associations of Marbled Murrelets in Clayoquot Sound, British Columbia. Ministry of Water, Land and Air Protection, Victoria, British Columbia, Canada. [online] URL: http://www.env.gov.bc.ca/wld/documents/techpub/ mamuwebs.pdf

Hall, L. S., P. R. Krausman, and M. L. Morrison. 1997. The habitat concept and a plea for standard terminology. Wildlife Society Bulletin 25:173-182.

Hamer, T. E. 1995. Inland habitat associations of Marbled Murrelets in western Washington. Pages 163-176. in C. J. Ralph, G. L. Hunt, Jr., and J. F. Piatt, editors. Ecology and conservation of the Marbled Murrelet. General Technical Report. PSW-GTR-152, Pacific Southwest Research Station, U.S. Forest Service, Albany, California, USA. [online] URL: http://www.fs.fed.us/psw/pub lications/documents/gtr-152/chap17.pdf

Hamer, T. E., D. E. Varland, T. L. McDonald, and D. Meekins. 2008. Predictive model of habitat suitability for the Marbled Murrelet in western Washington. Journal of Wildlife Management 72:983-993. http://dx.doi.org/10.2193/2006-565

Johnson, D. H. 1980. The comparison of usage and availability measurement for evaluating resource preference. Ecology 61:65-71. http://dx.doi.org/10. $\underline{2307 / 1937156}$

Johnson, M. D. 2007. Measuring habitat quality: a review. Condor 109:489-504. http://dx.doi.org/10.1 $\underline{650 / 8347.1}$

Jones, J. 2001. Habitat selection studies in avian ecology: a critical review. Auk 118:557-562. http:// dx.doi.org/10.1642/0004-8038(2001)118[0557:HSSIAE] 2.0.CO:2 
Manley, I. A. 1999. Behaviour and habitat selection of Marbled Murrelets nesting on the Sunshine Coast. Thesis, Simon Fraser University, Burnaby, British Columbia, Canada.

Meyer, C. B. 2007. Does scale matter in predicting species distributions? Case study with the Marbled Murrelet. Ecological Applications 17:1474-1483. http://dx.doi.org/10.1890/06-1410.1

Meyer, C. B., S. L. Miller, and C. J. Ralph. 2004. Stand-scale habitat associations across a large geographic region of an old-growth specialist, the Marbled Murrelet. Wilson Bulletin 116:197-210. http://dx.doi.org/10.1676/03-122

Naslund, N. L., K. J. Kuletz, M. B. Cody, and D. K. Marks. 1995. Tree and habitat characteristics and reproductive success at Marbled Murrelet tree nests in Alaska. Northwestern Naturalist 76:12-25. http: //dx.doi.org/10.2307/3536739

Nelson, S. K. 1997. Marbled Murrelet (Brachyramphus marmoratus). No. 276 in A. Poole and F. Gill, editors. The birds of North America. The Academy of Natural Sciences, Philadelphia, Pennsylvania, and The American Ornithologists' Union, Washington, D.C., USA.

Piatt, J. F., K. J. Kuletz, A. E. Burger, S. A. Hatch, V. L. Friesen, T. P. Birt, M. L. Arimitsu, G. S. Drew, A. M. A. Harding, and K. S. Bixler. 2007. Status review of the Marbled Murrelet (Brachyramphus marmoratus) in Alaska and British Columbia. Open-File Report 2006-1387, U.S. Geological Survey, Reston, Virginia, USA. [online] URL: http ://pubs.usgs.gov/of/2006/1387/

Raphael, M. G., D. E. Mack, and B. A. Cooper. 2002. Landscape-scale relationships between abundance of Marbled Murrelets and distribution of nesting habitat. Condor 104:331-342. http://dx.doi. org/10.1650/0010-5422(2002)104[0331:LSRBAO] 2.0.CO;2

Resource Inventory Standards Committee. 2001. Inventory methods for Marbled Murrelets in marine and terrestrial habitats: standards for components of British Columbia's biodiversity. No. 10. Version 2.0. Resource Inventory Standards Committee, Victoria, British Columbia, Canada. [online] URL: http://archive.ilmb.gov.bc.ca/risc/pubs/tebiodiv/ murrelet2k1/mamu\%20ml20.pdf
Rodway, M. S., and H. M. Regehr. 1999. Potential nesting density of Marbled Murrelets in valleybottom old-growth forests in Clayoquot Sound, British Columbia. Pacific Seabirds 26:3-7.

Silvergieter, M. P. 2009. Multi-scale analyses of nest site selection and fledging success by Marbled Murrelets (Brachyramphus marmoratus) in British Columbia. Thesis, Simon Fraser University, Burnaby, British Columbia, Canada.

U.S. Fish and Wildlife Service. 1997. Recovery plan for the threatened Marbled Murrelet (Brachyramphus marmoratus) in Washington, Oregon, and California. Region 1, U.S. Fish and Wildlife Service, Portland, Oregon, USA. [online] URL: htt p://ecos.fws.gov/docs/recovery plans/1997/970924. $\underline{\mathrm{pdf}}$

Waterhouse, F. L., A. E. Burger, D. B. Lank, P. K. Ott, E. A. Krebs, and N. Parker. 2009. Using the low-level aerial survey method to identify Marbled Murrelet nesting habitat. BC Journal of Ecosystems and Management 10(1):80-96.

Waterhouse, F. L., A. Donaldson, and D. B. Lank. 2004. Using airphotos to interpret Marbled Murrelet nesting habitat in British Columbia: application of a preliminary classification scheme. Forest Research Technical Report TR-029, Coast Forest Region, BC Ministry of Forests, Nanaimo, British Columbia, Canada. [online] URL: http://ww w.for.gov.bc.ca/rco/research/Mamu/tr029.pdf

Waterhouse, F. L., A. Donaldson, D. B. Lank, P. K. Ott, and E. A. Krebs. 2008. Using air photos to interpret quality of Marbled Murrelet nesting habitat in south coastal British Columbia. BC Journal of Ecosystems and Management 9(1):17-37. [online] URL: http://www.forrex.org/publications/jem/ISS47/ vol9 no1 art3.pdf

Whitlock, M. C. 2005. Combining probability from independent tests: the weighted Z-method is superior to Fisher's approach. Journal of Evolutionary Biology 18:1368-1373. http://dx.doi.o $\mathrm{rg} / 10.1111 / \mathrm{j} .1420-9101.2005 .00917 . \mathrm{x}$

Zharikov, Y., D. B. Lank, and F. Cooke. 2007. Influence of landscape pattern on breeding distribution and success in a threatened alcid, the Marbled Murrelet: model transferability and management implications. Journal of Applied 
Ecology 44:748-759. http://dx.doi.org/10.1111/j.13 65-2664.2007.01319.x

Zharikov, Y., D. B. Lank, F. Huettmann, R. W. Bradley, N. Parker, P. P.-W. Yen, L. A. McFarlane Tranquilla, and F. Cooke. 2006. Habitat selectivity and breeding success in a forest-nesting alcid, the Marbled Murrelet, in two landscapes with different degrees of forest fragmentation. Landscape Ecology 21:107-120. http://dx.doi.org/10.1007/s10 980-005-1438-5 